\title{
AN EMPIRICAL STUDY FOR LIFE INSURANCES: A CASE STUDY OF PILIYANDALA REGION
}

\author{
Lakshani JADS \\ Department of Mathematical Sciences \\ Wayamba University of Sri Lanka
}

\begin{abstract}
Life insurance is a very significant financial contract due to uncertainty of human life. It pave the way for policy holders to plan the future as their beneficiaries safely. However, the insurance industry plays a huge role in both private and public sector as a result of globalization and commercialization. Therefore, a vital competition is exists between private insurance companies in order to expand their businesses all over the world and to gain more profits. Hence, insurance companies often tend to offer different modes of life insurances to gladden customers. In the study, it has been considered the three main life insurances which are; whole life insurance, Term life insurance and Endowment life insurance. The aims of this study are to explore the impact of various demographic factors on customers life insurance investment decision and predict policy holder's behaviors. This research is significant to understanding existing market trends, develop new trading stations and facing market competition. Multinomial logistics regression was used to analyse the secondary data. The results of the quest indicates that the age, marital status, monthly income, gender, and monthly instalment are significant factors for purchasing a life insurance. Furthermore, endowment life insurance is the most efficient life insurance category in Piliyandala region. However, the insurer is able to form new explorations by conducting this research for other regions.
\end{abstract}

Keywords - Demographic factors, Life insurance, Multinomial logistics regression

\section{INTRODUCTION}

Life insurance is a financial contract between two parties, in which insurer guarantees payment of death benefit to the beneficiaries or dependents upon the death of the insured. At any time of the life, everyone have to face future uncertainties and anyone does not know those in advance. Therefore, it is important to ensuring solvency and consumer safety by using a financial plan as life insurance.

\author{
Napagoda NADN \\ Department of Mathematical Sciences \\ Wayamba University of Sri Lank
}

On the other hand, insurers trying to attract more customers with the purpose of having a great profit. Therefore, a market research is essential in order to going overboard the competitors. Hence, the study was carried out in order to explore the impact of various demographic factors on customers life insurance investment decision and predict policy holders behaviors. However, this study is significant for identify consumer behaviors and effective insurance categories. Furthermore, it is contributory to opulence and development of the insurance company. of the Three main life insurance categories were selected for this research. Those are; whole life insurance, term life insurance and endowment life insurance. Whole life insurance is a insurance which is guaranteed to remain in force for the insured's lifetime, provided required premiums are paid or to the maturity date. Term life insurance is a insurance that provides coverage at a fixed rate of payments for a limited period of time. Endowment insurance is insurance which offer lump sum benefit paid either on the death of the policy holder or at the end of the specified term whichever occurs first.

This paper is discussed literature reviews in section II and methodology in section III. Furthermore, data collection and analysis, results and discussion, conclusions and references are presented in section IV, V, VI and VII respectively.

\section{LITERATURE REVIEW}

Many previous researches had been conducted regarding insurance industry. It is noteworthy to study their researches in order to see about the areas which had not been enquired previously and to conduct a distinct study. On the other hand there are limited number of studies available.

However, Kuhlemeyer, A.G. (1999) has investigated consumer satisfaction with life insurance: A benchmarking survey. The research objective was exploring consumer satisfaction relevant to the purchase of life insurance products. $\mathrm{He}$ had considered the attitudes of insurances they offer,as factors and availability of agent or broker as a dependent variable. The research had showed that trust, competence and 


\section{International Journal of Engineering Applied Sciences and Technology, 2021 \\ Vol. 5, Issue 11, ISSN No. 2455-2143, Pages 72-76 \\ Published Online March 2021 in IJEAST (http://www.ijeast.com)}

product appropriateness play an integral part in consumer satisfaction.

Furthermore, Negi, D. and Singh, P. (2012) has studied demographic analysis of factors influencing purchase of life insurance products in India. Survey aims to find out relationship of demographic characteristics of respondents with brand quality, brand image, loyalty, friendliness and commitment. One way ANOVA was carried out to check whether no significant difference between the different factors motivating customers in favour of insurance product across different demographic categories. Product quality and brand image were the highest important factors according to their analysis.

In addition to that, Nena, S. (2013) conducted a study on performance evaluation of Life Insurance Corporation of India(LIC). The researcher had analysed the major source of income (Premium Earned) of the sampled unit, as well as the significant heads of expenses of LIC to measure the performance during the period of the study. The objective of this study was to know the growth and performance of LIC. Researcher had applied F-test for the testing hypothesis, as a method of performance evaluation. The performance evaluation demonstrated consistent increase in the organization. During the period of the study there was no major change in the financial performance of the LIC.

Further, Tiwari, A. and Yadav, B. (2012) has examined a study on factors affecting customers investment towards life insurance policies. The study area is limited to Jabalpur district, of madhya pradesh for small sample size and different private life insurers have been selected through a stratified and purposive sampling method. Their objective was, to study the factors influencing customers investment decision.

Therefore, the study is very significant when compared with the literatures, since this study has been analysed insurance category wise behaviors of the customers and insurance category wise impact of demographic factors. However, previous studies had only concerned the impact of factors for purchasing life insurances rather than insurance category wise impact and customer behaviors. Further, this study has predicted the customer behaviors towards the types of insurances.

\section{METHODOLOGY}

Multinomial logistics regression was conducted in order to analyse the impact of each selected demographic factor and assumptions were checked. In addition to that, pearson's correlations matrix was used to explore the relationships between insurance category and each factor.

General equation of the multinomial logistics regression as follows. $\log \{P(Y=j) / P(Y=J)\}=\alpha+\beta_{1} X_{1}+\beta_{2} X_{2}+\ldots+\beta_{k} X_{k}$ (1)

Where, $\mathrm{j}$ is the identified variable and $\mathrm{J}$ is the reference variable.

According to the general equation log odds of choosing term life insurance over whole life insurance and log odds of choosing endowment insurance over whole life insurance as follows respectively.

$\log \{\mathrm{P}(\mathrm{Y}=$ Term life insurance $) / \mathrm{P}(\mathrm{Y}=$ Whole life insurance $)\}$ $=\alpha+\beta 1 \mathrm{X} 1+\beta 2 \mathrm{X} 2+\ldots+\beta \mathrm{kXk}$ (2)

$\log \{\mathrm{P}(\mathrm{Y}=$ Endowment insurance $) / \mathrm{P}(\mathrm{Y}=$ Whole life insurance) $\}=\alpha+\beta 1 \mathrm{X} 1+\beta 2 \mathrm{X} 2+\ldots+\beta \mathrm{kXk}$ (3)

Then the predicted probabilities of the customers towards the three insurance categories were obtained using the model and accuracy of the model was checked.

\section{DATA COLLECTION AND ANALYSIS}

Study was based on secondary data obtained from regional insurance advisor and a small sample size was used to do the analysis. However, the dependent variable of this study is insurance categories and independent variables are age, gender, monthly income, marital status, and monthly instalment.

Computer software $\mathrm{R}$ was used to analyse the data.

\section{RESULTS AND DISCUSSION}

Fig. 1 interpreted that most preferred insurance category is endowment insurance and it is $79 \%$ from total policy holders. Term insurance and Whole life insurance policy holders are comparatively low due to low awareness of other insurance categories.

In the track of Fig. 2, distribution of male policy holders are approximately double as the distribution of female policy holders, in each insurance category. This could be happened due to masculine based society and low female workforce who has a conception.

According to the Fig. 3, majority of policy holders from Whole life insurance and term insurance are married persons whereas majority of policy holders from Endowment insurance are unmarried persons. However, the reason behind the distance between married and unmarried is the economy. 
pie chart of insurance categories

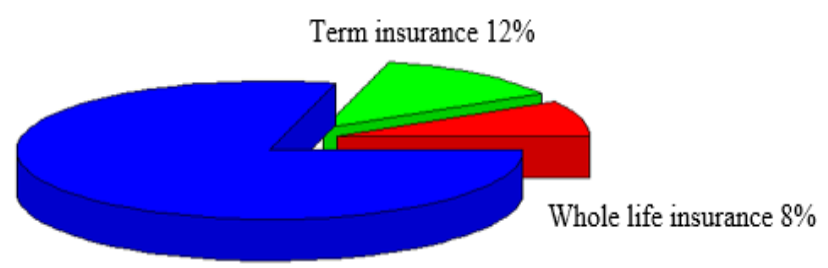

Endowment insurance $79 \%$

Fig. 1 : Insurance Category Wise Distribution

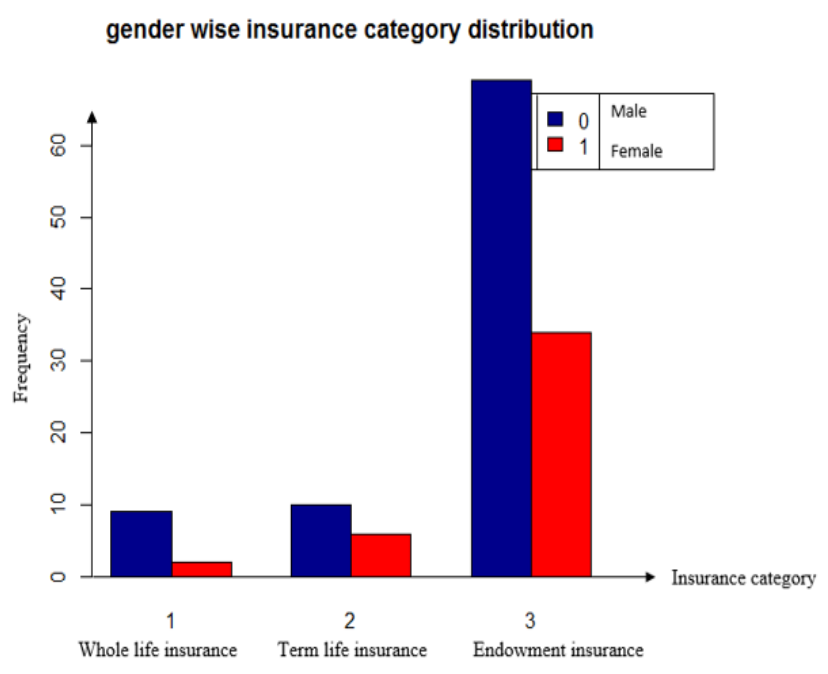

Fig. 2 : Gender Wise Insurance Category Distribution

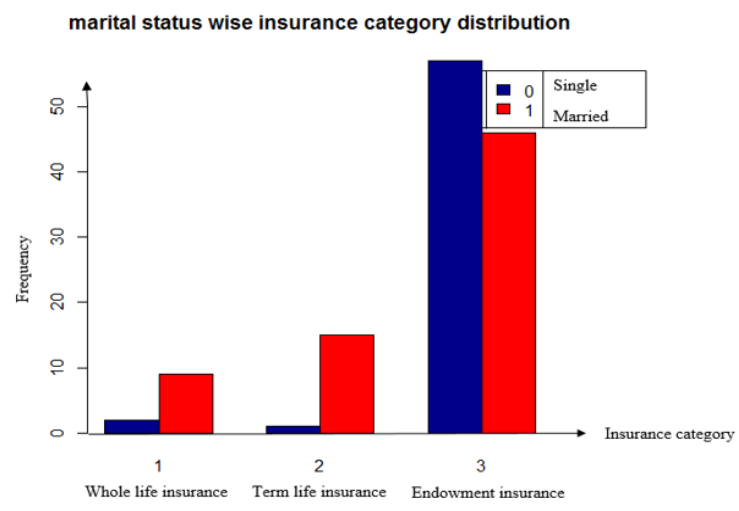

Fig. 3 : Marital Status Wise Insurance Category Distribution the baseline insurance category = "Whole life insurance" and the third row to insurance category = "Endowment insurance" to the baseline insurance category = "Whole life insurance".

$\mathrm{Y} 1=\ln (\mathrm{P}(\mathrm{Y}=$ Term life insurance $) / \mathrm{P}(\mathrm{Y}=$ Whole life insurance $))$ $=-1.397574+0.0476667 *$ (age) $+0.9327993 *$ (gender) $1.297601 \mathrm{e}-05^{*}($ monthly income $)+1.6172904 *$ (marital status)

A one-unit increase in age increases the chance of being a Term life insurance policy holder vs. Whole life insurance policy holder by 0.04766699 . A one-unit increase in monthly income decreases the chance of being a term life insurance policy holder vs. whole life insurance policy holder by $1.297601 \mathrm{e}-05$.

$\mathrm{Y} 2=\ln \quad(\mathrm{P}(\mathrm{Y}=$ Endowment insurance $) / \mathrm{P}(\mathrm{Y}=$ Whole life insurance) $=6.334218-0.07417227 *$ (age) $+0.4427339 *($ gender $) \quad-3.196600 \mathrm{e}-05 *($ monthly income $)+$ $0.1608159 *$ (marital status)

Equation (5) illustrates that the one unit increase in age and monthly income decreases the chance of being endowment policy holder vs whole life policy holder by 0.07417227 and $3.196600 \mathrm{e}-05$ respectively.

In addition to that, it is significant to defining and forecasting consumer behaviors based on the demonstrated model. According to the Table 2, there is 0.026895 probability of being whole life policy holder, 0.008911 probability of being term life policy holder and 0.964195 probability to being endowment policy holder for the first customer and it is obvious that the first customer is more likely to be a endowment life policy holder. It can be concluded that, most of customers have high probability to being endowment policy holders.

However, Table 3 indicates that the misclassification of actual vs predicted results. According to the matrix the first element denotes the actual category and the predicted category being whole life insurance. Second element represent the actual category being term life insurance and predicted category being whole life insurance. Third element states the actual category being endowment insurance and predicted being whole life insurance. Therefore, the diagonal elements are the correct classification of the model and upper and lower triangular matrices are the misclassifications of the model.

Hence, the misclassification of the model is $20 \%$. In another way, the model has probability of 0.2 to misclassifying a choice of a customer.
According to the summary output (Table 1) second row is being compared to insurance category $=$ "Term insurance" to 


\section{International Journal of Engineering Applied Sciences and Technology, 2021 \\ Vol. 5, Issue 11, ISSN No. 2455-2143, Pages 72-76 \\ Published Online March 2021 in IJEAST (http://www.ijeast.com)}

\section{CONCLUSION}

This study was conducted in order to explore the impact of various demographic factors on customers life insurance investment decision and predict policy holder's behaviours. It is significant to conducting a research to the company for identifying market trends, new opportunities and to expanding existing market. There are research limitations since the security of data, some demographic factors could not be taken for the study. At that rate, the study area is broaden and as a future study, this research can be conducted for other regions to get a general inference.

Multinomial logistics regression analysis was conducted to determine the associate factors to encourage for purchasing insurance policy. The results perceived that, age, gender, monthly income, marital status and monthly instalment were significant factors for this study. Derived regression model has $80 \%$ of accuracy when predicting an assortment of new customer. In other words, model has $20 \%$ probability of misclassifying a new customer's choice towards these three insurance categories.

Finally, it can be concluded that, most efficient insurance category among peoples in the Piliyandala region is Endowment life insurance and the life insurance company can improve their sales by generating new rewards systems and remuneration packages targeting on the 25-35 age group. However, it appears that males have a more purchasing power rather than females in the society of considered region.

Table 1: Coefficients of Multinomial Logistics Regression Model
Table 2: Predicted Probabilities of First six Customers

\begin{tabular}{|c|l|l|l|}
\hline $\begin{array}{l}\text { Order of } \\
\text { customers }\end{array}$ & $\begin{array}{l}\text { Whole life } \\
\text { insurance }\end{array}$ & $\begin{array}{l}\text { Term life } \\
\text { insurance }\end{array}$ & $\begin{array}{l}\text { Endowment } \\
\text { insurance }\end{array}$ \\
\hline 1 & 0.026895 & 0.008911 & 0.964195 \\
\hline 2 & 0.011652 & 0.009073 & 0.979276 \\
\hline 3 & 0.419124 & 0.232074 & 0.348803 \\
\hline 4 & 0.143472 & 0.252832 & 0.603696 \\
\hline 5 & 0.05919 & 0.470565 & 0.470245 \\
\hline 6 & & \multicolumn{2}{|l}{} \\
\hline \multicolumn{2}{|l|}{} & & \\
\hline
\end{tabular}

Table 3: Confusion Matrix

\begin{tabular}{|l|l|l|l|}
\hline & $\begin{array}{l}\text { Whole } \\
\text { life } \\
\text { insurance }\end{array}$ & $\begin{array}{l}\text { Term life } \\
\text { insurance }\end{array}$ & $\begin{array}{l}\text { Endowment } \\
\text { insurance }\end{array}$ \\
\hline Actual category & & 1 & 3 \\
\hline $\begin{array}{l}\text { Whole life } \\
\text { insurance }\end{array}$ & 2 & & \\
\hline $\begin{array}{l}\text { Term life } \\
\text { insurance }\end{array}$ & 0 & 3 & 1 \\
\hline & & & \\
$\begin{array}{l}\text { Endowment } \\
\text { insurance }\end{array}$ & 9 & 12 & 99 \\
\hline
\end{tabular}

\begin{tabular}{|l|l|l|l|l|l|l|}
\hline & (Intercept) & Age & Gender & Monthly_Income & Monthly_Installment & Marital_Status \\
\hline $\begin{array}{l}\text { Term Life } \\
\text { Insurance }\end{array}$ & -1.397574 & 0.04766699 & 0.9327993 & $-1.297601 \mathrm{e}-05$ & $-9.493333 \mathrm{e}-05$ & 1.6172904 \\
\hline $\begin{array}{l}\text { Endowment } \\
\text { Insurance }\end{array}$ & 6.334218 & -0.0741722 & 0.4427339 & $-3.196600 \mathrm{e}-05$ & $9.452482 \mathrm{e}-05$ & 0.1608159 \\
\hline
\end{tabular}




\section{International Journal of Engineering Applied Sciences and Technology, 2021 \\ Vol. 5, Issue 11, ISSN No. 2455-2143, Pages 72-76 \\ Published Online March 2021 in IJEAST (http://www.ijeast.com)}

\section{REFERENCES}

[1] Basaula, D. (2017). Customer Satisfaction Towardslife Insurance Claim Settlement In Nepal, Janapriya Journal of Interdisciplinary Studies, (pp.29-44), vol. 6

[2] Batool, A. and Sahi, A.(2016). Determinants of Financial Performanceof Insurance Companies Of USA And UK During Global Financial Crisis (2007-2016), International Journal of Accounting Research, (pp.1-9), $\operatorname{vol.7(1)}$

[3] Bedi, H.S. and Singh, P. (2011). An Empirical Analysis Of Life Insurance Industry In India, International Journal of Multidisciplinary Research, (pp.62-73), vol. 1(7)

[4] Kuhlemeyer, A.G. (1999). Consumer Satisfaction With Life Insurance:A Benchmarking Survey, Association for financial counseling and planning education, (pp. 35-49), vol. 10(2)

[5] Nagentran, $M$ and Rajendran, R. (2017). Economic Analysis of Crop Insurance : A Critical Review, Shanlax International Journal of Economics, (pp.25-31), vol.5(2)

[6] Negi, D. and Singh, P. (2012). Demographic Analysis of Factors Influencing Purchase of Life Insurance Products in India, European Journal of Business and Management, (pp.169-180), vol. 4(7)

[7] Nena, S. (2013). Performance Evaluation of Life Insurance Corporation of India (LIC) , International journal of advance research in computer science and management studies, (pp. 113-118),vol. 1,(7)

[8] Rashid, A. and Kemal, M.S (2018). Impact of Internal (Micro) and External (Macro) Factors on Profitability of Insurance companies, Journal of Economic Policy Researches, (pp.35-57), vol.5(1)

[9] Robson, J. and Sekhon, Y. (2011). Addressing the research needs of the insurance sector, International Journal of Bank Marketing, (pp.512-516), vol.29(7)

[10] Senthilkumar, N. and Selvamani, K. (2016). Life Insurance Industry in India, International Journal of Research- Granthaalayah, (pp.30-36), vol.4

[11] Tiwari, A. \& Yadav, B. (2012). A Study on Factors Affecting Customers Investment Towards Life Insurance Policies, International journal of marketing, financial services and management research, (pp.106-123), vol. 1, (7)
[12] Zyka, E. and Myftaraj, E. (2014). Factors Affecting The Insurance Sector Development : Evidence From Albania, Romanian Economic Journal, (pp.171-188), vol.17 (51) 